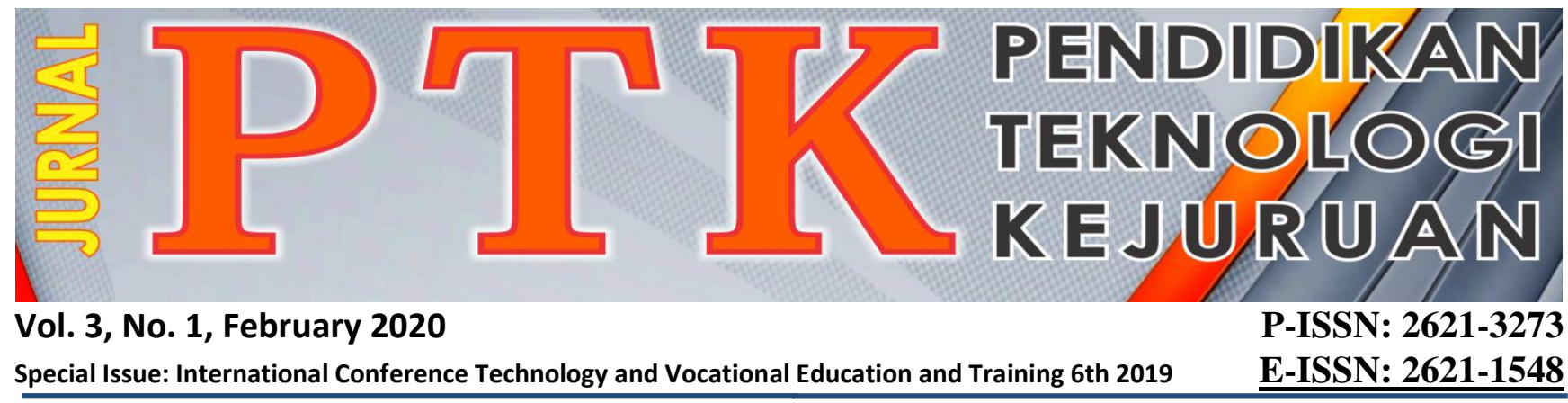

\title{
ALTERNATIVE CONCEPTS TO IDENTIFY THE CHARACTERISTICS OF VOCATIONAL TECHNOLOGY EDUCATION CURRICULUM
}

\author{
Nadia Utari and Riki Mukhaiyar \\ ${ }^{1 *}$ Vocational Technology Education, Faculty of Enginering, Universitas Negeri Padang \\ ${ }^{2}$ Electrical Engineering Department, Faculty of Enginering, Universitas Negeri Padang \\ "Corresponding author, e-mail: nadia.utari79@gmail.com
}

\begin{abstract}
Higher education is expected to produce excellent graduates to meet the needs of educated and skilled personnel in the era of industry 4.0. One way of higher education to adjust the development of Science and Technology in the era of industry 4.0 is by enriching the curriculum. Curriculum enrichment can be done by adding a new course, the Image Processing course. Image Processing is a course in Electrical Engineering which discusses data processing and analyze data in the form of images to be used as important information as requested. Image processing courses are widely used in daily life, implementation of image processing courses are found in smartphones, parking systems, medical, television and many others that utilize image processing subjects. The characteristics of this study compared two different groups: the Non-LPTK University (Lembaga Pendidikan Tenaga Kependidikan/ Educaitonal Institutions of Educatinal Staff) with the LPTK University to looking for characteristics in covering different subjects with the characteristics of vocational education, but it is related to the characteristics of vocational education in considering matching subjects with digital characteristics in the field of vocational education studies. Curriculum enrichment aims to improve the quality of higher education learning which leads to improve the quality of graduates. The researcher used a qualitative research with a comparative method ex post facto. This research is expected to be a pattern for other universities in applying curriculum enrichment methods.
\end{abstract}

Keywords: Curriculum Enrichment, Vocational Education, Image Processing

Copyright (C) 2020 JPTK. All rights reserved

\section{INTRODUCTION}

Without appropriate and good curriculum, it will be difficult to achieve the educational goals and objectives because the curriculum determines the types and qualifications of graduates of an educational institution. After the publication of the Indonesian Qualification Framework on Higher Education, it encouraged all universities in Indonesia to adjust to the provisions described [1]. In order for graduates produced by tertiary institutions to have the ability equivalent to the learning outcomes that have been formulated in the IQF qualification level, inputting new courses is something that usually occurs in every curriculum. In order for the curriculum in higher education to be good, evaluation on the curriculum must be carried out in its application. Curriculum development is a process that takes place continuously and forms a cycle that starts from planning, implementation and ending with evaluation [2]. Curriculum development is very important because it will greatly determine the type and quality of one's knowledge and experience to achieve good life and livelihood [3]. Curriculum enrichment is an activity to find out and decide which programs have been undertaken that are still appropriate or not appropriate with the objectives set [4]. Curriculum enrichment plays an important role in determining educational policy as well as in decision making in the curriculum [5]. Curriculum is a plan in education that has a very significant role in education, if the curriculum provided to students is suitable and of good quality, so that it will directly affect graduates. Therefore, curriculum enrichment 
or evaluation is needed by increasing or reducing courses [6,7].

For each college including UNP (Universitas Negeri Padang) especially Electrical Engineering Vocational Education (EEVE), regular and planned curriculum evaluation is a correction to the role of higher education [8]. Curriculum enrichment demands can be caused by changing needs or the ongoing curriculum is no longer able to meet growing needs. On this basis, curriculum enrichment is a form of responsibility of universities in carrying out continuous improvements to their duties and obligations in carrying out educational programs. Curriculum compilation cannot be done rashly, a solid foundation is needed so that it can be utilized in conducting educational activities, so that it can be easier to achieve practical and effective learning directions [9]. The achievements and objectives of learning can be utilized by stakeholders from educational programs run by UNP always to get the actual results and the best benefits of their time.

The stakeholders of Electrical Engineering Vocational Education (EEVE) is to become a professional educator in sectors that require mentors in vocational schools, vocational training centers, companies and other industries (scientific installations, energy generators and regulatory systems) [10]. To compensate for the developments entering the era of industry 4.0, higher education is expected to produce excellent graduates to meet the needs of educated and skilled personnel at this time. It is appropriate for the UNP Electrical Engineering Vocational Education it is better to take into account courses that are in harmony with current conditions. One of the courses that should be considered is the Image Processing course with the many factors of implementation of today's. The Image Processing is a course to improve student expertise in the current Electrical Engineering field which is a method used to process or manipulate images in two-dimensional form to be made into real physical into three dimensions [11]. Digital Image Processing is a discipline that studies image processing techniques, the image referred to here is still images (photos) and moving images (video), while digital is image or image processing done digitally using a computer [12].

Based on these explanations, it is important to carry out further research on the study of curriculum enrichment by conducting a scientific process in the Electrical Engineering Vocational Education study program at Padang State University by focusing on Image processing course. The characteristics of this study are to find new subject input methods, which are different from the characteristics of vocational education in Electrical Engineering, but it is appropriate with the characteristics of vocational education in considering to input subjects that are in line with digital characteristics in the field of vocational education studies.

\section{METHODOLOGY}

In this study researchers used qualitative research methods ex post facto computational causal approach. The purpose of this study was to obtain a concept of injecting Non-LPTK curriculum into the LPTK curriculum, about the characteristics of the Image Processing course, so that later the Image Processing course can be said, appropriate or not with work requirements and what is the basis for whether or not the eyes are suitable lecture on Image Processing with the needs desired by users of graduates who are one of the stakeholders of the EEVE study program.

The comparative method is to compare the four curriculum of Non-LPTK University of Electrical Engineering and the curriculum of the LPTK University of EEVE study program to look for curriculum characteristics in covering the Image Processing course. The researchers looked for the characteristics of the Non-LPTK curriculum that were different from the characteristics of the vocational education curriculum, but it is adjusted to the characteristics of vocational education to consider inputting the Image Processing course at the LPTK University. There are four Non-LPTK Universities, which are used as research objects: Universitas Indonesia (UI), Universitas Gadjah Mada (UGM), Institut Teknologi Bandung (ITB) and Universitas Andalas (UNAND) Meanwhile the LPTK universities are: Universitas Negeri Yogyakarta (UNY), Universitas Pendidikan Indonesia (UPI), Universitas Negeri Jakarta (UNJ), and Universitas Negeri Padang(UNP). The reason the researchers made these universities as the object of comparison was because the university had a benchmarking as the most qualified Non-LPTK and LPTK universities in Indonesia.

The researchers analogous (compared) the Non LPTK University curriculum in looking for the characteristics of the Image Processing course in the field of Electrical Engineering consisting of, major and elective courses. Researchers examined the Image Processing course of Non LPTK universities through syllabus and RPS, so the researchers found that the characteristics of the course were appropriate or not appropriate, if inputted to the LPTK Universities especially the UNP Electrical Engineering Vocational Education Study Program. 


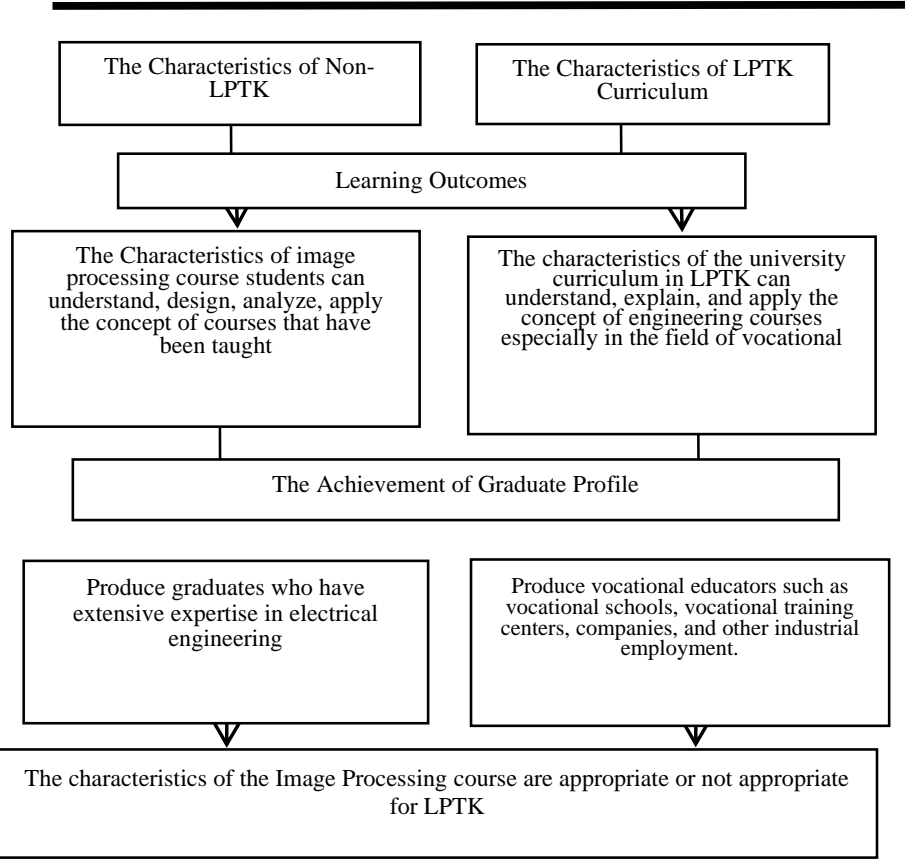

Figure 1. The Chart of Research Methodology

\section{RESULTS AND DISCUSSION}

\section{A. Non-LPTK University Curriculum in Electrical Engineering}

In this study, researchers examined the RPS comparison of the Image Processing course, researchers found the characteristics of the Image Processing course as follows: understanding, explaining, analyzing, and getting concepts obtained during the Image Processing course from Higher Education so that graduates from Electrical Engineering can design, handle problems and applying knowledge in engineering. Learning achievement is an accumulation of the entire learning process taken by a student while studying in a study program. The achievement of learning is expected to be appropriate with their respective functions should not eliminate the core elements of learning achievement itself: affective, cognitive and phsycomotor. According to the results of this study it can be explained that, the Non LPTK university curriculum in terms of RPS Image Processing subjects researchers get its characteristics as follows:

Table 1. The Characteristics of the Non-LPTK

\begin{tabular}{|c|c|c|c|c|}
\hline \multicolumn{5}{|c|}{ Curriculum. } \\
\hline Indicator & UNAND & UI & UGM & ITB \\
\hline $\begin{array}{l}\text { Learning } \\
\text { Outcomes }\end{array}$ & $\begin{array}{l}\text { Can design, } \\
\text { process, and } \\
\text { apply the } \\
\text { concepts of } \\
\text { signal and } \\
\text { system } \\
\text { courses }\end{array}$ & $\begin{array}{l}\text { Can } \\
\text { understand, } \\
\text { explain and } \\
\text { analyze the } \\
\text { concepts of } \\
\text { signal } \\
\text { courses and } \\
\text { systems }\end{array}$ & $\begin{array}{l}\text { Can analyze } \\
\text { and apply the } \\
\text { concepts of } \\
\text { subject } \\
\text { processing } \\
\text { techniques }\end{array}$ & $\begin{array}{l}\text { Can } \\
\text { understand, } \\
\text { analyze and } \\
\text { apply the } \\
\text { concept of } \\
\text { image } \\
\text { processing } \\
\text { courses }\end{array}$ \\
\hline
\end{tabular}

\section{B. LPTK University Curriculum in Electrical \\ Engineering Vocational Education}

In this section the researcher has obtained the results of research that the learning outcomes of engineering courses at LPTK universities, namely: can explain and understand the theory of engineering courses. Based on the learning achievements of graduates at LPTK universities, namely to become professional teachers in their fields by mastering engineering competence and pedagogical abilities in vocational schools as a whole, being able to adjust to the industrial world, and being able to communicate both verbally and in writing. The results of this study were found through the LPTK university curriculum based on syllabus and engineering RPS that can be described in the table below:

Table 2. The Characteristics of the LPTK Curriculum.

\begin{tabular}{|c|c|c|c|c|}
\hline Indicator & UNP & UNY & UNJ & UPI \\
\hline $\begin{array}{l}\text { Learning } \\
\text { Outcomes }\end{array}$ & $\begin{array}{l}\text { Can } \\
\text { understand } \\
\text { and apply } \\
\text { basic } \\
\text { concepts } \\
\text { from } \\
\text { engineering } \\
\text { courses }\end{array}$ & $\begin{array}{l}\text { Can } \\
\text { understand } \\
\text { and explain } \\
\text { the basic } \\
\text { concepts of } \\
\text { engineering } \\
\text { courses }\end{array}$ & $\begin{array}{l}\text { Can } \\
\text { understand } \\
\text { and apply the } \\
\text { basic } \\
\text { concepts of } \\
\text { engineering } \\
\text { courses }\end{array}$ & $\begin{array}{l}\text { Can } \\
\text { understand, } \\
\text { explain, and } \\
\text { apply the } \\
\text { concept of } \\
\text { engineering } \\
\text { courses }\end{array}$ \\
\hline
\end{tabular}

From the research findings, the researchers obtained an overview of the curriculum of NonLPTK universities and LPTK universities so that they could summarize the differences in the two different characteristics in the table below.

Table 3. The Graduate Profile Achievement of NonLPTK and LPTK Curriculum.

\begin{tabular}{|l|l|l|}
\hline \multicolumn{1}{|c|}{ Indicator } & \multicolumn{1}{|c|}{ Non-LPTK } & \multicolumn{1}{c|}{ LPTK } \\
\hline $\begin{array}{l}\text { Achievement } \\
\text { of Graduate } \\
\text { Profile }\end{array}$ & $\begin{array}{l}\text { Produce graduates } \\
\text { who have extensive } \\
\text { expertise so that they } \\
\text { have competence in } \\
\text { the field of electrical } \\
\text { engineering }\end{array}$ & $\begin{array}{l}\text { Produce } \\
\text { educators in various fields } \\
\text { who need educators, such } \\
\text { as vocational schools, } \\
\text { vocational training } \\
\text { centers, companies, and } \\
\text { other industrial } \\
\text { employment. }\end{array}$ \\
\hline
\end{tabular}

From the results of the study showed that the characteristics of the Non-LPTK curriculum in the Image Processing course showed compatibility with the characteristics of the LPTK curriculum, especially in the Electrical Engineering Education study program. The comparative method compared to the Non-LPTK curriculum through the Image Processing Course RPS in the scope of the material the researchers discussed are: the principles of digital images, digital image characteristics, and methods of improving image quality. Learning Achievement of this Image Processing course is expected that students will be able to explain, understand, and apply the scientific theory of the Image Processing course. This is synonymous with the characteristics of the LPTK curriculum, researchers found digital characteristics of vocational education through engineering courses at the LPTK university in this case the learning outcomes of LPTK's keen subjects are students able 
to explain, understand, and apply scientific theories of technical courses in Educational courses Electrical Engineering. In this study the characteristics of the Non LPTK curriculum in the Image Processing course are in line with the engineering curriculum in the LPTK curriculum. Therefore, there is a need for enrichment or curriculum evaluation by adding or reducing courses [7].

Vocational technology education curriculum must be able to anticipate the competency requirements in the future and the needs of students to organize the future able to innovate in the values of society [14].Vocational technology education curriculum must be able to anticipate the competency requirements in the future and the needs of students to organize the future. This Image Processing course is able to overcome the digital utilization in the future, in this case the researchers hope that the Electrical Engineering Education study program UNP can consider the Image Processing course to be included in its curriculum, because in teaching and learning Vocational Technology Education must pay attention to trends in the world of work in the future, globalization, localization, individualization to be independent, employable and to be a vehicle of transition for individuals to the world of work [15].

\section{CONCLUSION}

From the results of analysis and discussion it can be concluded that that by recognizing the characteristics of the curriculum by reviewing the characteristics of the curriculum in the Image Processing course from several Non-LPTK universities can be aligned and appropriate with the characteristics of UNP Electrical Engineering Vocational Education which is one of the LPTK Universities. As a drafter, this paper is expected to be an opening illustrator for the next LPTK curriculum study, especially for Electrical Engineering Vocational Education study program

\section{REFERENCES}

[1] Kemenristekdikti. Guide to Jakarta Higher Education Curriculum Development Directorate General of Learning and Student Affairs pp 1-2. 2016.

[2] Schubert W H. Curriculum: Perspective, Paradigm, and Possibility. New York: Macmillan Publishing Co. 1986.

[3] Rusdi, R. The Concept of Curriculum Development Padang UNP Press. 2012.
[4] Busro, M 2017 Media Academy's Curriculum Planning and Development. Yogyakarta.

[5] Sukmadinata N S. The Development of Curriculum Theory and Practice Bandung Youth. Rosdakarya. 2010.

[6] Perception of Dolgan RAC and Altun S. Teachers' Perceptions on the Effectiveness of Curriculum Mapping: the Case of Turkey Journal of Educational and Instructional Studies in the World vol 3 no 4 pp 50-60. 2013.

[7] Konokman GY, Yelken TY, Karasolak K, and Cesur E. Teacher's Perception: Competent or Not in Online Journal of Educational Curriculum Development Malaysian vol 5 issue 4 pp 56-73. 2017.

[8] Andalas University Education and Quality Assurance Agency (LP3M). Guidelines for Preparation and Evaluation of Andalas Padang Curriculum. 2015.

[9] Mukhaiyar R. Study of Organizing the Curriculum Study Programs at the UNP Electrical Engineering Department as a Reference Policy for Other LPTK Universities In Proceeding of KONASPI VIII 2018 pp 97-102. 2016.

[10] UNP Electrical Engineering. Vision, Mission and Objectives of Electrical Engineering Education, State University of Padang(http://elektro.ft.unp.ac.id/index.php/visimisi-dan-tujuan- 3/). 2019.

[11] Purwandari E P. Improving the Quality of Learning Digital Image Processing in the Informatics Engineering Study Program Using. Project Based Learning Model Vol. 2 no 53-62. 2014.

[12] Sutoyo. T, Mulyanto. Edy, Suhartono. Vincent, Dwi Nurhayati Oky, Wijanarto, Digital Image Processing Theory, Andi Yogyakarta and UDINUS Semarang, 2009.

[13] Mukhaiyar, R., Mukhaiyar, Myori, D.E., Hambali, Utari, N. 2019. Reorganizing the Curriculum of the Study Programs of the Electrical Engineering Fields in Universitas Negeri Padang as Its Eminent Policy. Journal of Physics: Conference Series: 1387. 012043, pp. 14. 2019.

[14] Mukhaiyar, Utari S, and Mukhaiyar R. English as a Second Language for an International Nursery Student in United Kingdom In Proceeding of The 4th UPI International Conference on Technical and Vocational Education and Training pp 107114. 2016.

[15] Sudira, P. Kurikulum Dan Pembelajaran Pendidikan Dan Pelatihan Vokasi Menyongsong Skill Masa Depan Makalah Pengembangan Kurikulum Politeknik Negeri Bali: pp 1-2. 